\title{
STUDYING THE DEVELOPMENT FACTORS OF STUDENTS' CREATIVITY BASED ON Q-METHODOLOGY
}

\author{
Vyacheslav Kazarenkov \\ Peoples' Friendship University of Russia, Russian Federation \\ Bui Thuy \\ Hanoi National University of Education, Viet Nam \\ Tatyana Kazarenkova \\ International Scientific Center “SOCIUM 2035”, Russian Federation \\ Galina Kameneva \\ Peoples' Friendship University of Russia, Russian Federation
}

\begin{abstract}
In educational science today, there are many studies on the factors associated with students' creativity using various research methods. A new feature of our current study is to use Q-methodology to explore the teacher's perspective on the factors influencing students' creativity in the teaching process. We investigated the views of 42 lecturers working at three universities in Vietnam including Hanoi National University of Education, Can Tho University of Medicine and Pharmacy, National University of Civil Engineering. Results of $Q$-sort implementation of participants are processed using a special software dedicated to $Q$ methodology - Ken-Q Analysis version 1.0.6. The results of the study indicated that there are two factors affecting the development of the students' creativity. Factor 1 extracted was named as the psychological characteristics of the students themselves. Factor 1 with an eigenvalue of 22.79 accounted for 54\% of the study variance and consisted of 23 lecturers defining for this factor. Factor 2 was named as characteristics of the teaching activity of teachers. It accounted for $8 \%$ of the study variance with an eigenvalue of 3.38 and contained 19 lecturers. These factors accounted for $62 \%$ of the total study variance. The results are considered as important suggestions for teachers and students to achieve the purpose of developing creative personalities. Moreover, this also is an instruction for educational managers to improve the quality of education at universities.
\end{abstract}

Keywords: Creativity, factor, lecturer, Q-methodology, student.

\section{Introduction}

Creative human resources are considered as conditions determining the success of each country in the globalization process in all fields. Continual changes in modern society require education to constantly improve the quality of training. Creating highly creative human resources is seen as the task of every 
education in every nation. Sadeghi and Ofoghi insisted in their research that: "One of the most important factors for the higher education systems is promoting creativity of their students" (Sadeghi \& Ofoghi, 2011, p.263). In the study (Hamed, Preece, \& Hashim, 2016), it is stated that creativity is an essential element of teaching and learning that brings delight and meaningfulness to the classroom and to students' learning experiences. Therefore, identifying the factors that develop students' creativity is the first concern of educational researchers in the modern world.

The purpose of our current study is to use Q-methodology to explore the perspective of Vietnamese teachers at different universities on the factors influencing students' creativity in the teaching process. The research results are considered as a valuable discovery to apply in the teaching process at universities with the aim of developing students' creativity. The essence of Qmethodology is a unique combination of the strengths of both qualitative and quantitative research technique that allows researchers to investigate the subjective viewpoints of participants on a research topic. It can be applied to improve the quality of educational research. However, this methodology is less applicable to previous educational studies. The use of Q-methodology is a new approach for this study.

\section{Literature review}

Various aspects of students' creativity have been explored in previous studies. It is believed (Ramankulov et al., 2016) that information and communication technologies are an effective means of formation of the creative potential of future physics teachers. In the research on teachers' creative teaching behaviors, (Hong et al., 2009) it is concluded that nine key factors that can affect teachers' creative teaching behaviors, namely personal quality, thinking style, family factor, education experience, teaching belief, personal effort, motivation, professional knowledge, and environmental factor. In the study (Hamed et al., 2016), it is concluded that creative teaching is influenced by four main factors: personal knowledge, personal efforts, teaching commitment and teaching beliefs. Richardson and Mishra have built an instrument to design creative learning environments in their study. It consists of three categories: physical environment; learning climate; and learner engagement (Richardson \& Mishra, 2018). The creative teacher is considered an important factor to enhance students' creativity. Kazarenkov stated that the creativity of a teacher is impossible without self-knowledge, self-improvement, self-realization (Kazarenkov, 2011).

The relationship between creativity in the learning process and other factors is also explored in the following studies: creativity and academic 
achievement (Habibollah et al., 2010), creativity and intelligence (Shrivastava, 2016), creativity and self-efficacy (Tamannaeifar \& Motaghedifard, 2014), thinking and creative styles (Wechsler, Vendramini, \& Oakland, 2012).

A new feature of our research is a holistic approach from two central elements of the learning process: teaching activities of teachers and learning activities of students. We identify all the elements that are relevant to teachers and students to bring about the development of students' creativity.

\section{Methodology}

The Q-methodology emerged in 1935, when the English physicist and psychologist William Stephenson presented it in a letter to the "Nature" journal (Brown, 1993). He was interested in finding new methods to study individual beliefs and attitudes. Currently, the use of the Q-method is significantly increasing in research in the field of psychology, social psychology, politics, etc (Mokry \& Dufek, 2014).

Q-methodology was used to explore the perspective of Vietnamese teachers on the factors influencing students' creativity in the teaching process. We have used various methods to collect information related to research topic such as interviews, surveys, summarizing results of previous scientific publications and pilot study on a small group of 15 teachers. The Q-sample used in this study included 56 statements related to the different aspects of the teaching process. This is a collection of statements selected from the total number of statements that have been collected by various methods. The statements are numbered and printed on cards. The study involved 42 lecturers from various faculties at three universities in Vietnam including Hanoi National University of Education, Can Tho University of Medicine and Pharmacy, National University of Civil Engineering. The study sample consisted of 22 males and 20 females. The age of the lecturers is from 27 to 51 . Teachers were asked to directly sort these cards into Q-grid according to printed instructions. The Q grid in this study consists of 11 point scale (from -5 to +5 ). The results of the $Q$ grid were carefully photographed and recorded in the results table of each study participant. The collected data is processed by specialized software for Q- methodology - Ken-Q Analysis version 1.0.6 (Banasick, 2019). Research data were analyzed by the varimax method and using the principal components.

\section{Research results}

The results of the $\mathrm{Q}$ grid of 42 lecturers were included in the factor analysis. The results showed that two factors were identified as accounting for 
Kazarenkov et al., 2020. Studying the Development Factors of Students' Creativity Based on Q-Methodology

$62 \%$ of the study variance. Detailed results are shown in Table 1 . Lecturers with a significant loading on a factor define that factor.

The significance of the factor loading of respondents (at $\mathrm{p}<0.01$ ) is calculated by the following Formula 1 created by the author (Tiernon, Hensel, \& Roy-Ehri, 2017).

$$
2.58 / \sqrt{n}
$$

where $\mathrm{n}$ - number of statements in Q-sample

Table 1 Factor loadings of respondents performing Q-sorting

\begin{tabular}{|c|c|c|c|c|c|}
\hline \multirow{2}{*}{ Lecturer } & \multicolumn{2}{|c|}{ Factor loadings } & \multirow{2}{*}{ Lecturer } & \multicolumn{2}{c|}{ Factor loadings } \\
\cline { 2 - 3 } \cline { 5 - 6 } & Factor 1 & Factor 2 & & Factor 1 & Factor 2 \\
\hline 1 & $0.64 \mathrm{x}$ & $0.37 \mathrm{x}$ & 22 & $0.73 \mathrm{x}$ & 0.27 \\
\hline 2 & $0.73 \mathrm{x}$ & $0.35 \mathrm{x}$ & 23 & -0.10 & $0.75 \mathrm{x}$ \\
\hline 3 & $0.46 \mathrm{x}$ & $0.48 \mathrm{x}$ & 24 & 0.00 & $0.58 \mathrm{x}$ \\
\hline 4 & $0.66 \mathrm{x}$ & $0.36 \mathrm{x}$ & 25 & $0.43 \mathrm{x}$ & $0.77 \mathrm{x}$ \\
\hline 5 & $0.52 \mathrm{x}$ & $0.49 \mathrm{x}$ & 26 & 0.30 & $0.70 \mathrm{x}$ \\
\hline 6 & $0.75 \mathrm{x}$ & 0.30 & 27 & 0.29 & $0.80 \mathrm{x}$ \\
\hline 7 & $0.75 \mathrm{x}$ & $-0,05$ & 28 & 0.31 & $0.73 \mathrm{x}$ \\
\hline 8 & $0.75 \mathrm{x}$ & 0.31 & 29 & $0.42 \mathrm{x}$ & $0.72 \mathrm{x}$ \\
\hline 9 & $0.73 \mathrm{x}$ & 0.27 & 30 & $0.46 \mathrm{x}$ & $0.75 \mathrm{x}$ \\
\hline 10 & $0.49 \mathrm{x}$ & $0.41 \mathrm{x}$ & 31 & 0.33 & $0.69 \mathrm{x}$ \\
\hline 11 & $0.81 \mathrm{x}$ & 0.04 & 32 & $0.44 \mathrm{x}$ & $0.81 \mathrm{x}$ \\
\hline 12 & $0.68 \mathrm{x}$ & $0.40 \mathrm{x}$ & 33 & $0.42 \mathrm{x}$ & $0.82 \mathrm{x}$ \\
\hline 13 & $0.76 \mathrm{x}$ & 0.27 & 34 & $0.42 \mathrm{x}$ & $0.82 \mathrm{x}$ \\
\hline 14 & $0.81 \mathrm{x}$ & 0.28 & 35 & $0.53 \mathrm{x}$ & $0.73 \mathrm{x}$ \\
\hline 15 & $0.81 \mathrm{x}$ & 0.28 & 36 & $0.57 \mathrm{x}$ & $0.57 \mathrm{x}$ \\
\hline 16 & 0.14 & $0.45 \mathrm{x}$ & 37 & $0.70 \mathrm{x}$ & $0.49 \mathrm{x}$ \\
\hline 17 & $0.54 \mathrm{x}$ & 0.32 & 38 & $0.78 \mathrm{x}$ & $0.43 \mathrm{x}$ \\
\hline 18 & 0.14 & $0.45 \mathrm{x}$ & 39 & $0.65 \mathrm{x}$ & $0.57 \mathrm{x}$ \\
\hline 19 & $0.66 \mathrm{x}$ & $0.37 \mathrm{x}$ & 40 & $0.58 \mathrm{x}$ & $0.66 \mathrm{x}$ \\
\hline 20 & 0.24 & $0.49 \mathrm{x}$ & 41 & $0.73 \mathrm{x}$ & $0.48 \mathrm{x}$ \\
\hline 21 & $0.78 \mathrm{x}$ & 0.14 & 42 & $0.72 \mathrm{x}$ & $0.48 \mathrm{x}$ \\
\hline
\end{tabular}

$X$ : indicates a significance factor loading of respondents on one factor

In the current study, 56 statements were was created in Q-sample, therefore, the Formula 1 becomes $2.58 / \sqrt{ } 56=0.34$. The factor loading of each lecturer is statistically significant on factor 1 or factor 2 or both when $\geq 0.34$.

Table 1 shows that 11 lecturers significantly loaded on factor 1; 9 lecturers significantly loaded on factor 2; 22 lecturers - both factors 1 and 2.

For example, lecturer 6 correlates 0.75 with factor 1 . Lecturer 16 correlates 0.45 with factor 2 . Student 1 correlates with both factors 1 and 2. (0.64 and 0.37). 
From the data in Table 1, there are more than 50\% of the lecturers significantly loaded on both factor 1 and factor 2 . This shows the consensus relationship between these two factors in developing students' creativity in the learning process.

Table 2a Factor scores for statements (-5 to 5)

\begin{tabular}{|c|c|c|c|}
\hline \# & Statement & Factor 1 & Factor 2 \\
\hline 1 & Knowledge of the discipline is easy to understand and remember & $-1^{\mathrm{b}}$ & $-3^{\mathrm{b}}$ \\
\hline 2 & Democratic culture in the assessment, consideration of opinions & $0^{\mathrm{a}}$ & $2^{\mathrm{b}}$ \\
\hline 3 & $\begin{array}{l}\text { The teacher sets the standards for creative requirements in the learning } \\
\text { process }\end{array}$ & $-1^{\mathrm{b}}$ & $3^{\mathrm{b}}$ \\
\hline 4 & The student has creative knowledge, skills and experience & $3^{\mathrm{b}}$ & $0^{\mathrm{b}}$ \\
\hline 5 & The teacher has a high academic degree & $-4^{\mathrm{b}}$ & $-2^{\mathrm{b}}$ \\
\hline 6 & The teacher does not use active methods in the learning process & -3 & -3 \\
\hline 7 & $\begin{array}{l}\text { The teacher rarely uses teaching tools to promote student creativity in the } \\
\text { learning process. }\end{array}$ & -4 & -4 \\
\hline 8 & The classroom did not have enough equipment to support creative activity. & $-3^{b}$ & $-4^{b}$ \\
\hline 9 & $\begin{array}{l}\text { The university has a policy of encouraging the creativity of students and } \\
\text { teachers. }\end{array}$ & $2^{b}$ & $-1^{\mathrm{b}}$ \\
\hline 10 & Learning tasks are very complex and difficult & -2 & -3 \\
\hline 11 & $\begin{array}{l}\text { In assessing learning results, the teacher highly appreciates new, unique } \\
\text { and useful products. }\end{array}$ & $1^{\mathrm{b}}$ & $3^{\mathrm{b}}$ \\
\hline 12 & Discipline has interesting, necessary knowledge. & $1^{\mathrm{a}}$ & $0^{\mathrm{a}}$ \\
\hline 13 & The teacher has an attractive appearance & -3 & -3 \\
\hline 14 & $\begin{array}{l}\text { The student has a confident, risky character and the courage to accept } \\
\text { defeat }\end{array}$ & $5^{\mathrm{b}}$ & $0^{\mathrm{b}}$ \\
\hline 15 & The teacher uses fun elements in teaching. & $0^{\mathrm{b}}$ & $4^{\mathrm{b}}$ \\
\hline 16 & Learning activities do not stimulate the imagination, curiosity of students & -4 & -4 \\
\hline 17 & Student's family highly appreciates creativity in everyday life & $1^{\mathrm{b}}$ & $-2^{\mathrm{b}}$ \\
\hline 18 & $\begin{array}{l}\text { The teacher is ready to support the creative process of students during } \\
\text { classes }\end{array}$ & $2^{\mathrm{b}}$ & $5^{b}$ \\
\hline 19 & The student has attention and effort in the learning process. & $2^{\mathrm{b}}$ & $0^{\mathrm{b}}$ \\
\hline 20 & Teaching activity of teachers creates motivation for students creat & $2^{b}$ & $5^{\mathrm{b}}$ \\
\hline 21 & The student has friends in the group who have creative thinking. & -2 & -2 \\
\hline 22 & University usually organizes creative experience activities & $1^{\mathrm{b}}$ & 2 \\
\hline 23 & The student can participate in many activities in the group & 2 & $3^{\mathrm{b}}$ \\
\hline 24 & $\begin{array}{l}\text { The student has a need to develop creative competence in the learning } \\
\text { process }\end{array}$ & $3^{b}$ & $1^{\mathrm{b}}$ \\
\hline 25 & $\begin{array}{l}\text { There is no learning consciousness in the class: students are often late, do } \\
\text { not actively cooperate with teachers and other students in the group. }\end{array}$ & -5 & -4 \\
\hline 26 & $\begin{array}{l}\text { The teacher has observation, satisfaction the various needs of students in } \\
\text { the group }\end{array}$ & $0^{\mathrm{b}}$ & $4^{\mathrm{b}}$ \\
\hline 27 & $\begin{array}{l}\text { The arrangement of tables and chairs is suitable for carrying out a variety } \\
\text { of activities in the classroom }\end{array}$ & -2 & -1 \\
\hline 28 & The teacher guarantees temperature, lighting in the classroom & $-2^{\mathrm{b}}$ & $-1^{b}$ \\
\hline
\end{tabular}

${ }^{a}$ significant distinguishing statement at $p<0.05$;

${ }^{b}$ significant distinguishing statement at $p<0.01$. 

Q-Methodology

A factor score is a score for a statement as a "kind of average" of the scores given that statement by all of the Q-sorts associated with the factor [3]. In the study using Q methodology, the factor score is the main basis for factor interpretations. The names of two extracted factors are called by the names of statements with high factor scores.

In our study, we explored the perspective of Vietnamese teachers on the factors influencing students' creativity in the teaching process. The results of the study indicated that there are two factors affecting the development of the students' creativity. Factor 1 extracted was named as the psychological characteristics of the students themselves. Factor 2 was named as characteristics of the teaching activity of teachers.

\section{Factor 1 - The psychological characteristics of the students themselves}

Factor 1 with an eigenvalue of 22.79 accounted for 54\% of the study variance and consisted of 23 lecturers defining for this factor.

In factor 1, Vietnamese lecturers viewed a high level of agreement with the following statements: "The student has a confident, risky character and the courage to accept defeat" (14: $\left.+5^{* *}\right)$; "The student has a positive attitude, interest in creative activity" (36: $+5^{* *}$ ); "The student has curiosity and active awareness" (41: $\left.+4^{* *}\right)$; "Students have confidence in their creativity" (33: $+4 * *)$; "Student has internal motivation for creativity" (53: $+4 * *)$; "Student has creative thinking and creative habit" $(44:+4)$; “The student has creative knowledge, skills and experience" $\left(04:+3^{* *}\right)$; "The student has a need to develop creative competence in the learning process" $\left(24:+3^{* *}\right)$.

Factor 2 - Characteristics of the teaching activity of teachers.

Factor 2 with an eigenvalue of 3.38 accounted for $8 \%$ of the study variance and consisted of 19 lecturers defining for this factor.

In factor 2, Vietnamese lecturers viewed a high level of agreement with the following statements: "The teacher is ready to support the creative process of students during classes" (18: $\left.+5^{* *}\right)$; “Teaching activity of teachers creates motivation for students creativity" $\left(20:+5^{* *}\right)$; "The teacher is a model example of creativity" (31: $\left.+4^{* *}\right)$; "Style of leadership, management and organization of classes teachers" (40: $+4 * *)$; "The teacher has observation, satisfaction the various needs of students in the group" $\left(26:+4^{* *}\right)$; "The teacher uses fun elements in teaching” $\left(15:+4^{* *}\right)$. 
Table $2 b$ Factor scores for statements (-5 to 5) (continued)

\begin{tabular}{|c|c|c|c|}
\hline$\#$ & Statement & Factor 1 & Factor 2 \\
\hline 29 & $\begin{array}{l}\text { The teacher and students have a positive relationship in the learning } \\
\text { process }\end{array}$ & $3^{\mathrm{a}}$ & $3^{b}$ \\
\hline 30 & Students' high intelligence leads to high creative abilities & -1 & 0 \\
\hline 31 & The teacher is a model example of creativity & $0^{\mathrm{b}}$ & $4^{\mathrm{b}}$ \\
\hline 32 & The university has creative clubs & -1 & 0 \\
\hline 33 & Students have confidence in their creativity & $4^{\mathrm{b}}$ & $1^{\mathrm{b}}$ \\
\hline 34 & The teacher refuses to answer students' questions outside of class time & -5 & -5 \\
\hline 35 & The teacher has awards for students who have creative achievements & 0 & 1 \\
\hline 36 & The student has a positive attitude, interest in creative activity & $5^{\mathrm{b}}$ & $1^{\mathrm{b}}$ \\
\hline 37 & The teacher provides fairness and objectivity in the assessment of students & $0^{\mathrm{b}}$ & $3^{\mathrm{a}}$ \\
\hline 38 & Combining the assessment of teachers and students in the learning process & 1 & 1 \\
\hline 39 & The content of the discipline includes many practical exercises & -1 & -1 \\
\hline 40 & Style of leadership, management and organization of classes teachers & $1^{\mathrm{b}}$ & $4^{\mathrm{b}}$ \\
\hline 41 & The student has curiosity and active awareness & $4^{\mathrm{b}}$ & $2^{\mathrm{b}}$ \\
\hline 42 & Students are stimulated to new ideas. & 3 & 2 \\
\hline 43 & The teacher does not use group forms of teaching & -4 & -5 \\
\hline 44 & Student has creative thinking and creative habit. & $4^{\mathrm{b}}$ & $1^{\mathrm{b}}$ \\
\hline 45 & The student has independence in solving learning tasks & $2^{\mathrm{b}}$ & $0^{\mathrm{b}}$ \\
\hline 46 & The teacher who has studied abroad & $-3^{b}$ & $-2^{b}$ \\
\hline 47 & The teacher allows students to solve learning problems in their own way & 3 & 3 \\
\hline 48 & In a collective has a collaborative, friendly psychological atmosphere. & 1 & 2 \\
\hline 49 & The student lives in a creative collective & $0^{\mathrm{b}}$ & $-2^{\mathrm{b}}$ \\
\hline 50 & The health status of students in the group & $-2^{\mathrm{b}}$ & $-1^{\mathrm{b}}$ \\
\hline 51 & $\begin{array}{l}\text { The psychological atmosphere of a group of students in the process of } \\
\text { interaction }\end{array}$ & 0 & 1 \\
\hline 52 & The number of students in the class is small ( $\leq 50$ students) & -2 & -1 \\
\hline 53 & Student has internal motivation for creativity & $4^{\mathrm{b}}$ & $2^{\mathrm{b}}$ \\
\hline 54 & The economic condition of the student family & -3 & -3 \\
\hline 55 & Student lives in a family with a democratic atmosphere & -1 & -1 \\
\hline 56 & Student's parents are examples of creativity & $-1^{\mathrm{a}}$ & $-2^{\mathrm{a}}$ \\
\hline
\end{tabular}

${ }^{a}$ significant distinguishing statement at $p<0.05$;

${ }^{b}$ significant distinguishing statement at $p<0.01$.

\section{Conclusion}

Our current study is to use Q-methodology to explore the 42 lecturers' perspectives at three universities in Vietnam on the factors influencing students' creativity in the teaching process. The results of the study indicated that there are two factors affecting the development of the students' creativity. Factor 1 The psychological characteristics of the students themselves. Factor 2 Characteristics of the teaching activity of teachers. Each factor includes many different elements. These two factors have close relationships in the teaching process. The outcome of one factor affects the development of the other. The 
Kazarenkov et al., 2020. Studying the Development Factors of Students' Creativity Based on Q-Methodology

perfect result of the development of the student's creativity is indispensable in one of two factors.

The results are considered as important suggestions for teachers and students to achieve the purpose of developing creative personalities. Moreover, this also is an instruction for educational managers to improve the quality of education at universities.

\section{References}

Banasick, S. (2019). Ken-Q Analysis (Version 1.0.6) [Software]. Retrieved from https://shawnbanasick.github.io/ken-q-analysis/ DOI:10.5281/zenodo.1300201

Brown, S.R. (1993). A primer on Q-methodology. Operant Subjectivity, 16, 91-138.

Hamed, P.K., Preece, A.S.D., \& Hashim, C.N. (2016). Factors influencing creative teaching among teachers in Islamic private schools in Kuala Lumpur. Retrieved from: http://www.iium.edu.my/capeu2016/wp-content/uploads/2017/02/031.pdf

Habibollah, N., Rohani, A., Tengku, Aizan, H., Sharir, J., \& Kumar, V. (2010). Relationship between creativity and academic achievement: A study of gender differences. Journal of American, 6, 181-190.

Hong, J.-C., Horng, J.-S., Lin, L.-J., Chang, S.-H., Chu, H.-C., \& Lin, C.-L. (2009). A Study of Influential Factors for Creative Teaching online: 15 February. Retrieved from http://conference.nie.edu.sg/paper/Converted\%20Pdf/ab00202.pdf

Kazarenkov, V.I. (2011). Tvorchestvo pedagoga kak sistema. Sistemnaja psihologija $i$ sociologija, 3, 109-114.

Mokry, S., \& Dufek, O. (2014). Q method and its use for segmentation in tourism. Procedia Economics and Finance, 12, 445-452.

Ramankulov, S., Usembayeva, I., Berdi, D., Omarov, B., Baimukhanbetov, B., \& Shektibayev, N. (2016). Formation of the Creativity of Students in the Context of the Education Informatization. International Journal of Environmental and Science Education, 11(16), 9598-9613.

Richardson, C., \& Mishra, P. (2018). Learning Environments that Support Student Creativity: Developing the SCALE. Thinking Skills and Creativity, 27, 45-54.

Sadeghi, A., \& Ofoghi, N. (2011). The psychological factors affecting students' creativity inside the class (CIC) (case study the University of Guilan, Iran). Procedia Social and Behavioral Sciences, 15, 263-270.

Shrivastava, S. (2016). Creativity and intelligence. International Journal of Recent Advances in Multidisciplinary Research, 3(3), 339-1344.

Tamannaeifar, M.R., \& Motaghedifard, M. (2014). Subjective well-being and its sub-scales among students: The study of role of creativity and self-efficacy. Thinking Skills and Creativity, 12, 37-42. DOI: http://dx.doi.org/10.1016/j.tsc.2013.12.003

Tiernon, P., Hensel, D., \& Roy-Ehri, L. (2017). Using Q methodology in quality improvement projects. Journal of Obstetric, Gynecologic \& Neonatal Nursing, 0(0), 1-8

Wechsler, S.M., Vendramini, C.M.M., \& Oakland, T. (2012). Thinking and creative styles: A validity study. Creativity Research Journal, 24, 235-242. DOI: http://dx.doi.org/10.1080/10400419.2012.677359 